\title{
IbM PENGEMBANGAN USAHA KRIPIK PISANG DALAM MENDUKUNG TERWUJUDNYA SIDOARJO SEBAGAI KOTA UKM DI INDONESIA
}

\author{
Hana Catur Wahyuni $^{(1)}$, Atikha Sidhi Cahyana ${ }^{(2)}$, Mulyono ${ }^{(3)}$. \\ $(1,2)$ Prodi Teknik Industri, Universitas Muhammadiyah Sidoarjo \\ (3)Prodi Teknik Mesin, Universitas Muhammadiyah Sidoarjo \\ Email: ${ }^{(1)}$ hanacatur@umsida.ac.id
}

\begin{abstract}
ABSTRAK
Desa Gelam terletak di Kec Candi, Kabupaten Sidoarjo, \pm 5 km dari pusat kota Sidoarjo. Desa Gelam merupakan salah satu tujuan pemukiman bagi warga korban lumpur Sidoarjo. Sebagian besar warga desa Gelam bermata pencarian sebagai karyawan pabrik dan wirausaha. Bidang wirausaha yang paling banyak digeluti oleh warga desa Gelam adalah sektor makanan, salah satunya adalah pembuatan kripik pisang. Dalam perkembangannya terdapat permasalahan yang berkaitan dengan proses produksi, administrasi dan pemasaran. Ketiga faktor tersebut saat ini menghambat perkembangan usaha kripik pisang di desa Gelam, terutama dialami oleh mitra IbM, Target dan luaran yang diharapkan dari pelaksanaan program pengabdian masyarakat adalah: tersedianya mesin potong pisang untuk proses produksi usaha kripik pisang di desa gelam, Kec Candi Kab Sidoarjo, tersedianya sistem administrasi sehingga dapat digunakan untuk mengetahui perkembangan usaha kripik pisang. Oleh karena itu, untuk mengatasi permasalahan tersebut, maka solusi yang ditawarkan melalui pelaksanaan IbM adalah: solusi untuk permasalahan proses produksi adalah melalui IbM akan dibuat suatu mesin potong pisang, solusi untuk permasalahan administrasi adalah melalui penyusunan administrasi keuangan yang baik dan benar, sehingga dapat digunakan untuk melihat perkembangan usaha dan akses dana ke perbankan, solusi untuk masalah pemasaran adalah melalui pembuatan label yang menarik konsumen.
\end{abstract}

Kata kunci: kripik, administrasi, keuangan, pemasaran, konsumen

\section{ABSTRACT}

Gelam Village is located in Kec Candi, Sidoarjo Regency, $\pm 5 \mathrm{~km}$ from the center of Sidoarjo city. Gelam Village is one of the settlement destinations for Sidoarjo mudflow victims. Most of the residents of Gelam village have a search for factory employees and entrepreneurs. The field of entrepreneurship that most of the villagers in Gelam are involved in is the food sector, one of which is the manufacture of banana chips. In its development there were problems related to the production, administration and marketing processes. These three factors currently hamper the development of banana chips business in Gelam village, especially experienced by IbM partners, the targets and outcomes expected from the implementation of community service programs are: the availability of banana cutting machines for the production process of banana chips in Gelam village, Sidoarjo Regency. , the availability of an administration system so that it can be used to find out the business development of banana chips. Therefore, to overcome these problems, the solution offered through the implementation of IbM is: the solution to the problem of the production process is through IbM will be made a banana cutting machine, the solution to administrative problems is through the preparation of a good and correct financial administration, so that it can be used to see the development of businesses and access to funds to banks, the solution to the problem of marketing is through label making that attracts consumers.

Keywords: chips, administration, finance, marketing, consumers 


\section{PENDAHULUAN}

Usaha Mikro Kecil dan Menengah (UMKM) merupakan sektor yang mempunyai peranan penting dalam membangun perekonomi di Indonesia, karena sebagian besar jumlah penduduknya berpendidikan rendah dan hidup dalam kegiatan usaha kecil baik di sektor tradisional maupun modern. Dan mampu menyerap banyak tenaga kerja. Peranan usaha kecil tersebut menjadi bagian yang diutamakan dalam setiap perencanaan tahapan pembangunan yang dikelola Departemen Perindustrian dan Perdagangan, serta Departemen Koperasi dan UMKM (Hapsari, Hakim, \& Soeaidy, 2014). Salah satu faktor yang mempengaruhi pertumbuhan ekonomi Kabupaten Sidoarjo adalah UMKM. Dengan pertumbuhan ekonomi yang cukup pesat, pada tahun 2012 pertumbuhan ekonomi yang mencapai $7,08 \%$, kondisi ini sejalan dengan pengembangan bisnis usaha yang terus tumbuh dan berkembang di Sidoarjo. Potensi besar yang dimiliki Kabupaten Sidoarjo tidak akan berarti jika tidak diiringi dengan strategi pemberdayaannya, utamanya para pelaku UMKM itu sendiri dalam merebut dan menciptakan daya saing bagi produkproduknya dipasaran (Hafiluddin \& Saleh, 2014).

Desa Gelam terletak di Kec Candi, Kabupaten Sidoarjo, $\pm 5 \mathrm{~km}$ dari pusat kota Sidoarjo. Desa Gelam merupakan salah satu tujuan pemukiman bagi warga korban lumpur Sidoarjo. Sebagian besar warga desa Gelam bermata pencarian sebagai karyawan pabrik dan wirausaha. Bidang wirausaha yang paling banyak digeluti oleh warga desa Gelam adalah sektor makanan, salah satunya adalah pembuatan kripik pisang.

Pembuatan kripik pisang telah dilakukan sejak 2 tahun yang lalu. Hal ini sesuai dengan potensi desa, dimana sebagian besar lahan pekarangan warga desa ditanami dengan pohon pisang, sehingga bahan baku mudah diperoleh. Selain itu, pisang juga merupakan sumber vitamin, mineral dan karbohidrat (Direktorat Pengolahan Dan Pemasaran Hasil Hoktikultura, 2005).
Pisang memiliki manfaat dalam perlindungan dan pencegahan gigi dari kerusakan, dan bermanfaat untuk radang mulut dan gusi. Pisang mengandung zat besi dan vitamin $\mathrm{D}$, sehingga berguna dalam pence-gahan dan pengobatan anemia dan kekurangan zat Besi, dimana vitamin D mempermudah penyerapan zat Besi dalam usus. Vitamin D juga berguna untuk memperkuat gigi pada proses pembentukan gigi. Vitamin A juga terdapat dalam buah pisang dengan jumlah (300 IU per seratus gram), Penelitian terbaru menguatkan bahwa pisang mengandung hormon-hormon yang berfungsi untuk mengatur aktivitas sistem saraf (Rochmah, 2014).

Kemudahan memperoleh pisang di desa Gelam dan tingginya kandungan gizi pisang, menyebabkan permintaan pasar terhadap kripik pisang, sebagai salah satu olahan pisang sangat tinggi. Selain pisang lokal, sebenarnya bahan baku pisang juga dapat diperoleh dengan mudah Kab. Sidoarjo. Tetapi besarnya ketersediaan bahan baku tersebut tidak seluruhnya dapat diolah untuk menjadi kripik pisang. Hal tersebut disebabkan karena adanya beberapa permasalahan yang berkaitan dengan proses produksi, administrasi dan pemasaran. Ketiga faktor tersebut saat ini menghambat perkembangan usaha kripik pisang di desa Gelam, Permasalahan produksi yang sedang dihadapi oleh kedua mitra IbM disebabkan proses produksi kripik pisang dilakukan dengan peralatan - peralatan yang manual, terutama pada tahap pemotongan. Pemotongan pisang dilakukan dengan pisau dapur, sehingga hasil yang diperoleh tidak maksimal, baik dari sisi jumlah ataupun kualitas potongan.

Dari sisi jumlah, dengan pisau dapur hanya mampu memotong 2-3 tundun pisang per hari. Sedangkan dari sisi kualitas hasil potongan, penunjukkan bahwa tebal tipis potongan pisang tidak merata, ada yang terlalu tebal, ada yang terlalu tipis sehingga ketika digoreng mempunyai tingkat kematangan yang berbeda. Permasalahan lain yang dihadapi oleh mitra IbM adalah administrasi usaha. Selama ini usaha kripik 
pisang dijalankan tanpa ada administrasi apapun. Pelaku usaha tidak melakukan pencatatan - pencatatan terhadap semua transaksi yang dilakukannya, bahkan seringkali modal usaha tercampur dengan keuangan keluarga. Kondisi ini mengakibatkan tidak tersediannya laporan keuangan secara periodik. Padahal, laporan keuangan merupakan hal penting bagi pelaku usaha, terutama sebagai bahan evaluasi dan merupakan salah satu dokumen yang diperlukan untuk mengakses dana dari pihak perbankan. Ketidaktersediaan laporan keuangan kripik pisang, mengakibatkan perkembangan kripik pisang tidak terpantau dan pelaku usaha tidak dapat mengakses dana dari perbankan.

Selain itu, permasalahan kedua mitra IbM juga terjadi di bidang pemasaran. Selama ini, kripik pisang dipasarkan dengan cara yang sederhana, dikemas dalam plastik dan dititipkan diwarung - warung. Kemasan yang digunakan diberi label fotocopian, tidak menarik, tidak disertai alamat, ijin usaha atau tanggal kadaluwarsa. Hal ini menimbulkan keraguan konsumen untuk membeli, sehingga kripik yang dijual tidak 100\% laku. Akibatnya, pelaku usaha seringkali mengalami kerugian akibat kripik yang tidak terjual. Padahal, kemasan dan label merupakan salah satu strategi produk yang mampu meningkatkan daya saing produk dan tingkat kepercayaan konsumen terhadap produk (kottler, 2000). Pada lingkungan yang semakin kompetitif fungsi pengemasan telah berubah seiring perubahan gaya hidup konsumen yang cenderung bersifat selfservice, pengemasan menjadi sarana proposisi penjualan yang dapat merangsang perilaku pembelian konsumen, meningkatkan pangsa pasar, dan mengurangi biaya promosi (Kuvykaite \& Navickiene, 2009).

Jika permasalahan tersebut dibiarkan, maka akan menghambat perkembangan usaha kripik pisang, padahal usaha tersebut potensi untuk dikembangkan. Karena, usaha kripik pisang mampu menyerap ibu - ibu rumah tangga yang tidak bekerja sehingga mampu memperoleh penghasilan untuk membantu meningkatkan kesejahteraan keluarga. Selain itu, pertumbuhan usaha kripik pisang sangat diharapkan untuk menjadi Usaha Kecil Menegah (UKM) baru sehingga mampu mendorong terwujudnya program Pemerintah Sidoarjo, yaitu Menjadikan Sidoarjo Sebagai Kota Seribu UKM Indonesia.

Oleh karena itu, melalui program IbM diusulkan solusi untuk mengatasi permasalahan tersebut, yaitu dengan membuat suatu mesin potong pisang untuk mengatasi permasalahan produksi, pelatihan administrasi usaha untuk mengatasi masalah administrasi dan pelatihan strategi pemasaran melalui pembuatan label yang menarik konsumen, kemasan, pengurusan ijin usaha dan penentuan tanggal kadaluwarsa produk sebagai alat untuk mengatasi masalah pemasaran.

\section{METODE PELAKSANAAN}

1. Pembuatan mesin pemotong pisang. Pengusul menbuat mesin pemotong pisang dengan motor penggerak dinamo yang dapat dioperasikan secara mudah oleh pelaku usaha, sehingga dapat dihasilkan potongan pisang yang lebih banyak dengan kualitas irisan yang lebih bagus, dapat melakukan pemotongan pisang secara cepat dan berkualitas.

2. Pelatihan laporan keungan melalui penyusunan administrasi keuangan yang baik dan benar, sehingga dapat digunakan untuk melihat perkembangan usaha dan akses dana ke perbankan.

3. Pelatihan cara pemasaran adalah dengan mendatangkan tenaga ahli dan praktisi yang memahami cara pemasaran yang menarik.

\section{HASIL DAN PEMBAHASAN}

Kegiatan IbM telah dilaksanakan dalam rentang waktu bulan Maret s/d Oktober 2015. Kegiatan dimulai dengan membuat mesin pemotong pisang. Pembuatan mesin tersebut dilakukan melalui kerjasama dengan laboratorium Teknik Mesin Universitas Muhammadiyah Sidoarjo. Mesin potong pisang didesain dengan kecepatan tinggi dan hasil potongan pisang 
akan mempunyai ketebalan yang sama, sehingga ketika diigoreng dan dikemas akan terlihat rapi. Bentuk mesin yang dihasilkan adalah:

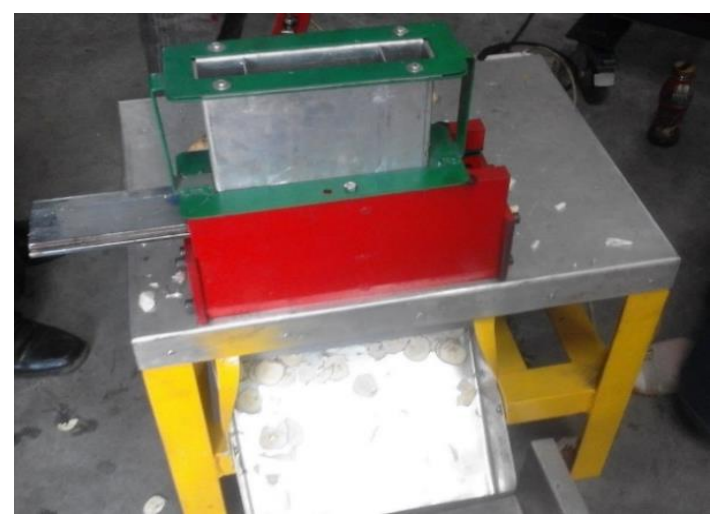

Gambar 1. Mesin Potong Pisang

Lebih dari itu, pisau mesin dapat diatur untuk mendapatkan ketebalan potongan pisang sesuai keinginan. Mesin potong pisang juga didesain untuk melakukan bentuk pemotongan yang berbeda, yaitu memanjang dan bulat. Kelebihan lain dari mesin ini adalah dapat digunakan untuk memoting ketela dan kentang.

Hasil yang dicapai berikutnya adalah terlaksananya pelatihan administrasi keuangan dan pemasaran. Dalam pelatihan administrasi keuangan, idealnya pelaku usaha melakukan pencatatan keuangan dalam buku besar, buku harian kas masuk dan buku harian kas keluar.

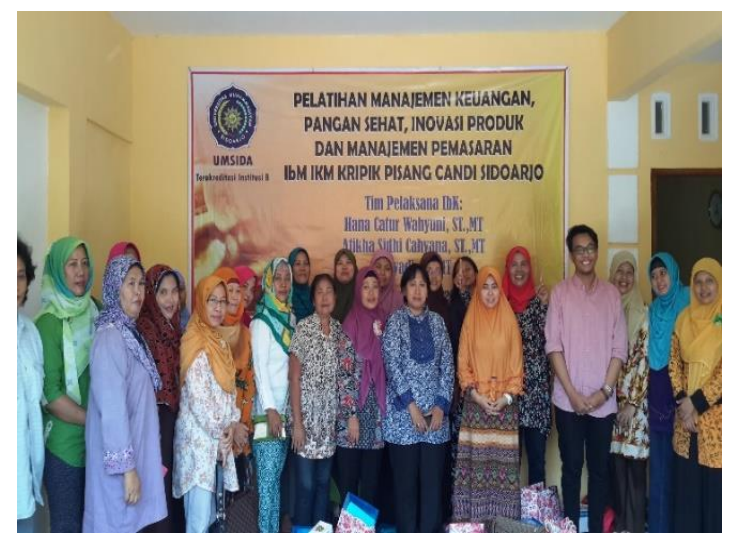

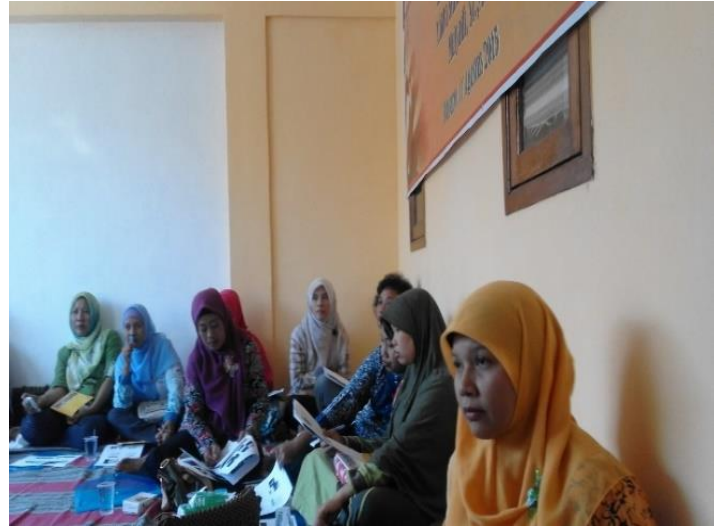

Gambar 2. Pelatihan administrasi usaha

\section{KESIMPULAN}

Permasalahan yang kerap terjadi pada usaha kripik pisang di desa gelam adalah proses produksi kripik pisang dalam hal pengirisan pisang masih manual tanpa memperhatikan kualitas, permasalahan yang lain adalah belum adanya sistem administrasi terutama pencatatan keuangan serta pemasaran yang tidak menarik minat konsumen untuk membeli. Dalam IbM ini pemberian mesin pemotong, pelatihan dan pendampingan manajemen keuangan serta cara pemasaran sehingga dalam jangka panjang daya saing kripik pisang dapat meningkat.

\section{REFERENSI}

Direktorat Pengolahan Dan Pemasaran Hasil Hoktikultura. (2005). Pasca Panen, Pengolahan Dan Pemasaran Hasil Pisang, 1-17.

Hafiluddin, M. R., \& Saleh, C. (2014). Strategi Pemberdayaan Usaha Mikro Kecil dan Menengah (UMKM) Berbasis "Community Based Economic Development" (Studi pada pelaku UMKM di Kecamatan Sukodono Kabupaten Sidoarjo), 17(2), 68-77.

Hapsari, P. P., Hakim, A., \& Soeaidy, S. (2014). Pengaruh Pertumbuhan Usaha Kecil Menengah (UKM) terhadap Pertumbuhan Ekonomi Daerah ( Studi 
VOL. 02. NO. 1, JULI 2018

di Pemerintah Kota Batu ), 17(2), 8896.

Kuvykaite, R., \& Navickiene, L. (2009). IMPACT OF PACKAGE ELEMENTS ON CONSUMER'S PURCHASE DECISION. Economic \& Management, 441-447.

Kottler, 2000, Manajemen Pemasaran, Prehanllindo, Jakarta.

Yayun Siti Rochmah, M. F. (2014). Pengaruh Penyuluhan Terhadap Perubahan Pengetahuan Bagi Ibu-Ibu Pkk Kelurahan Penggaron Lor Tentang Pemanfaatan. Odonto Dental Journal, 1(2), 1-5. 